\title{
WYKRYWANIE PODWÓJNEGO FINANSOWANIA WYDATKÓW W PROJEKTACH UNIJNYCH
}

\author{
Aneta Żbik \\ Politechnika Częstochowska \\ Wydział Zarządzania
}

\begin{abstract}
Streszczenie: Celem niniejszego artykułu jest omówienie zakazu podwójnego finansowania, jako jednej z głównych zasad zarządzania funduszami unijnymi, oraz instrumentów wykorzystywanych w celu wykrywania wielokrotnego finansowania tych samych wydatków ze środków publicznych. W artykule scharakteryzowano poszczególne instrumenty kontroli krzyżowych wykorzystywane przez Instytucje Zarządzające oraz Instytucję Koordynującą Narodowe Strategiczne Ramy Odniesienia w perspektywie finansowej 2007-2013, jak również nieprawidłowości wykrywane w obszarze podwójnego finansowania wydatków. W oparciu o informacje uzyskane $\mathrm{w}$ toku wywiadów przeprowadzonych z przedstawicielami Instytucji Zarządzającej Programem Operacyjnym Innowacyjna Gospodarka przedstawiono przyczyny naruszania zakazu podwójnego finansowania. W artykule zawarto również rekomendacje dla beneficjentów realizujących projekty unijne mające na celu ograniczenie ryzyka wystąpienia nieprawidłowości w przedmiotowym obszarze.
\end{abstract}

Słowa kluczowe: fundusze unijne, kontrola krzyżowa, podwójne finansowanie

DOI: $10.17512 /$ znpcz.2017.4.1.14

\section{Wprowadzenie}

Efektywne zarządzanie środkami funduszy strukturalnych zapewniające ochronę interesów finansowych Wspólnoty jest podstawowym celem każdego państwa członkowskiego Unii Europejskiej (Łukomska-Szarek, Szczepaniak 2011, s. 58-60). Zgodnie z pkt 66 preambuły Rozporządzenia Rady (WE) nr 1083/2006 z dnia 11 lipca 2006 r. jednym z podstawowych instrumentów mających zapewnić wydajną i prawidłową realizację programów operacyjnych jest system kontroli. Ciężar kontroli realizacji operacji wybranych do dofinansowania spoczywa na instytucjach odpowiedzialnych za wdrażanie programu pomocowego. Narzędziami monitorowania prawidłowości realizacji projektów są kontrole wniosków beneficjentów o płatność oraz kontrole projektów na miejscu realizacji. Powyższe narzędzia mają za zadanie zapewnić zgodność wdrażania projektu z dokumentacją aplikacyjną, umową o dofinansowanie, programem operacyjnym, prawem krajowym i unijnym oraz politykami wspólnotowymi.

Termin „kontrola”, pochodzący od francuskiego słowa „contrôle”, tłumaczy się w literaturze jako sterowanie, regulowanie, kontrolowanie, sprawdzanie, nadzorowanie, a nawet rejestrowanie (Duraj 2003, s. 9). Karol Adamiecki zdefiniował proces kontrolny jako sprawdzenie, czy wykonanie zgadza się z planem, czyli wzorcem (Adamiecki 1985, s. 232). Julian Gnoiński wskazał, że kontrola powinna wyznaczać 
drogę do osiągnięcia sprawności i skuteczności działania poprzez zdefiniowanie sposobu usunięcia stwierdzonych rozbieżności, katalogu niezbędnych do wdrożenia działań naprawczych oraz zapewnienie prawidłowej informacji o stanie rzeczywistym dla potrzeb zarządzania i kierowania (Gnoiński 1967, s. 50-51). Kontrola ma umożliwiać wykrywanie nieprawidłowości (Łęgowik--Świącik 2012, s. 50).

Kontrola, jako proces uniwersalny, występuje we wszystkich dziedzinach życia człowieka. Niezależnie od celu i przedmiotu działań kontrolnych obejmuje ona trzy kluczowe fazy: ustalenie norm, wzorców i standardów, porównanie stanu faktycznego z normami oraz korygowanie odchyleń od norm i planów (Kuc 2009, s. 25). Działania kontrolne realizowane są we wszystkich typach podmiotów funkcjonujących w gospodarce, począwszy od podmiotów prowadzących działalność biznesową, organizacje pozarządowe, aż po administrację rządową i samorządową. Kluczowe znaczenie należy przypisać kontrolom legalności realizowanym w podmiotach finansujących prowadzoną działalność lub jej część, wydzieloną w postaci projektu, ze środków publicznych (Zysińska 2007, s. 225). Powyższe wynika z konieczności przestrzegania zasad gospodarowania środkami publicznymi ${ }^{1}$.

Na państwach członkowskich Unii Europejskiej korzystających ze wsparcia finansowego funduszy strukturalnych i Funduszu Spójności ciąży obowiązek zapewnienia, zgodnie z art. 70 ust. 1 Rozporządzenia Rady (WE) nr 1083/2006 z dnia 11 lipca 2006 r., skutecznych i efektywnych systemów zarządzania i kontroli programów operacyjnych, zapobiegania, wykrywania i korygowania nieprawidłowości oraz odzyskiwania kwot nienależnie wypłaconych beneficjentom (Rozporządzenie Rady (WE) nr 1083/2006..., s. 34). Instytucja Zarządzająca odpowiada za zarządzanie programem operacyjnym oraz jego realizację zgodnie $\mathrm{z}$ zasadą należytego zarządzania finansami.

System kontroli programów operacyjnych perspektywy finansowej 2007-2013 jest przedmiotem badań teoretyków i praktyków gospodarczych. Przedmiotowe badania koncentrują się przede wszystkim na analizie procesu kontroli projektów unijnych oraz procedurach i procesach kontroli zarządczych realizowanych przez instytucje systemu wdrażania programów operacyjnych. W niniejszym artykule skoncentrowano się na jednym z obszarów systemu zarządzania i kontroli, jakim jest zapewnienie kwalifikowalności wydatków poprzez wykrywanie i eliminację podwójnego finansowania.

W oparciu o analizę danych zastanych, doświadczenie zawodowe autorki w obszarze realizacji i kontroli projektów unijnych oraz przeprowadzone badanie własne w publikacji zaprezentowano szczegółową analizę narzędzi wykrywania podwójnego finansowania wydatków. Artykuł identyfikuje najskuteczniejsze mechanizmy kontrolne w obszarze wykrywania i eliminacji podwójnego finansowania, wypełniając lukę $\mathrm{w}$ dotychczas przeprowadzonych badaniach systemów zarządzania i kontroli programów operacyjnych perspektywy finansowej 2007-2013.

\footnotetext{
${ }^{1}$ Zgodnie $\mathrm{z}$ art. 44 ust. 1 ustawy o finansach publicznych środki publiczne muszą być wydatkowane w sposób celowy i oszczędny, z zachowaniem zasad uzyskiwania najlepszych efektów z danych nakładów oraz optymalnego doboru metod i środków służących osiągnięciu założonych celów. $\mathrm{Na}$ mocy art. 5 ust. 1 pkt 2 przedmiotowej ustawy środkami publicznymi są środki pochodzące z budżetu Unii Europejskiej.
} 
Na potrzeby niniejszego artykułu w kwietniu 2017 r. przeprowadzono dwa indywidualne wywiady pogłębione z przedstawicielami Wydziału Kontroli Departamentu Programów Wsparcia Innowacji i Rozwoju Ministerstwa Rozwoju (Instytucji Zarządzającej Programem Operacyjnym Innowacyjna Gospodarka) posiadającymi doświadczenie zawodowe w obszarze kontroli projektów, kontroli systemowych oraz kontroli krzyżowych programu.

\section{Zakaz podwójnego finansowania wydatków}

U podstaw realizacji działań zmierzających do wykrywania i eliminacji wielokrotnego finansowania tych samych wydatków ze środków publicznych leży zakaz podwójnego finansowania. Wynika on $\mathrm{z}$ art. 54 ust. 5 Rozporządzenia Rady (WE) nr 1083/2006 z dnia 11 lipca 2006 r. Zgodnie z powyższym przepisem wydatki współfinansowane z funduszy nie mogą otrzymywać pomocy z innego wspólnotowego instrumentu finansowego. Zakaz znalazł odzwierciedlenie w art. 129 ust. 1 Rozporządzenia Parlamentu Europejskiego i Rady (UE, EURATOM) nr 966/2012 z dnia 25 października 2012 r., zgodnie z którym w żadnych okolicznościach te same wydatki nie mogą być dwukrotnie finansowane $\mathrm{z}$ budżetu. Zasada zakazu podwójnego finansowania została ukonstytuowana w art. 13 ust. 2 Rozporządzenia Komisji (WE) nr 1828/2006 z dnia 8 grudnia 2006 r. Zgodnie z powyższym weryfikacje prawidłowości realizacji operacji współfinansowanych ze środków unijnych obejmują procedury eliminujące możliwość równoległego finansowania wydatków z innych programów wspólnotowych lub krajowych albo w ramach innych okresów programowania (Redo 2014, s. 152-153).

Wytyczne horyzontalne w zakresie kwalifikowalności wydatków w perspektywie finansowej 2007-2013 wprowadziły definicję podwójnego finansowania wydatków. Zgodnie z pkt 6.5.1 dokumentu podwójne finansowanie oznacza niedozwolone zrefundowanie (lub rozliczenie) całkowite lub częściowe danego wydatku dwa razy ze środków wspólnotowych lub z dotacji krajowych. Zgodnie z przytoczoną definicją podwójnym finansowaniem jest w szczególności (MRR 2010, s. 24-25):

- zrefundowanie dwa razy tego samego wydatku ze środków publicznych, np. wynagrodzenia księgowej $\mathrm{w}$ ramach dwóch różnych projektów współfinansowanych ze środków publicznych lub prefinansowanie kosztów realizacji projektu z preferencyjnej pożyczki udzielanej ze środków publicznych (np. z realizowanej przez BGK Inicjatywy Jeremie), a następnie zrefundowanie poniesionych wydatków w ramach projektu współfinansowanego ze środków funduszy strukturalnych lub Funduszu Spójności;

- zrefundowanie kosztu poniesionego podatku VAT ze środków funduszy strukturalnych lub Funduszu Spójności² a następnie odzyskanie naliczonego podatku VAT z urzędu skarbowego;

\footnotetext{
${ }^{2}$ Powyższe możliwe jest w przypadku zadeklarowania przez beneficjenta na etapie składania wniosku o dofinansowanie braku prawnej możliwości odzyskania podatku VAT poniesionego w trakcie realizacji projektu.
} 
- zakup środka trwałego z udziałem krajowych środków publicznych (np. z dotacji na uruchomienie działalności gospodarczej przyznanej przez urząd pracy), a następnie zrefundowanie kosztów amortyzacji zakupionego środka trwałego w ramach projektu finansowanego z funduszy unijnych lub Funduszu Spójności;

- zrefundowanie wydatku poniesionego przez leasingobiorcę na zakup dobra leasingowanego beneficjentowi $\mathrm{w}$ ramach leasingu finansowego, a następnie zrefundowanie rat opłacanych przez beneficjenta $\mathrm{w}$ związku $\mathrm{z}$ leasingiem tego dobra.

Wprowadzenie powyższego zakazu na gruncie funduszy unijnych ma na celu zapewnienie ochrony środków publicznych, w tym wydatkowania ich w sposób efektywny. Działania zmierzające do wykrycia i eliminacji podwójnego finansowania realizowane są przez instytucje zaangażowane we wdrażanie programów operacyjnych (Instytucje Zarządzające, Instytucje Pośredniczące i Instytucje Wdrażające), Instytucję Koordynującą Narodowe Strategiczne Ramy Odniesienia (IK NSRO) oraz zewnętrzne podmioty kontrolujące prawidłowość realizacji projektów/programów operacyjnych (Instytucja Audytowa oraz Najwyższa Izba Kontroli).

\section{Narzędzia wykrywania podwójnego finansowania wydatków w ramach NSRO 2007-2013}

Wystąpienie podwójnego finansowania, jako jedno z kryteriów oceny kwalifikowalności wydatków (Domiter, Marciszewska 2013, s. 178), monitorowane jest przez każdą z Instytucji Zarządzających programami operacyjnymi, na wielu etapach wdrażania programu, począwszy od etapu aplikowania przez wnioskodawców o środki unijne, przez realizację projektu, okres trwałości, aż po zakończenie realizacji programu operacyjnego. W ramach każdego z programów operacyjnych Instytucja Zarządzająca realizuje kontrole krzyżowe programu oraz kontrole krzyżowe horyzontalne z projektami PROW 2007-2013 oraz PO RYBY 2007-2013. Dodatkowo IK NSRO przeprowadza kontrolę dokumentów księgowych pod kątem wielokrotnego rozliczania tych samych wydatków w ramach różnych programów operacyjnych jednej perspektywy finansowej oraz pomiędzy programami operacyjnych dwóch okresów programowania, tj. 2004-2006 i 2007-2013 (Szymański 2012 , s. 19). Charakterystykę narzędzi wykrywania podwójnego finansowania stosowanych w perspektywie finansowej 2007-2013 przedstawiono w Tabeli 1 .

Za realizację kontroli krzyżowych programu odpowiedzialna jest Instytucja Zarządzająca. W przypadku powierzenia wdrażania działań/poddziałań innym podmiotom, na mocy zawartych porozumień, Instytucje Pośredniczące lub Instytucje Wdrażające mogą realizować działania mające na celu wykrywanie i eliminację podwójnego finansowania tych samych wydatków w granicach powierzonych uprawnień. Instytucja Zarządzająca może również powierzyć przeprowadzenie kontroli krzyżowych podmiotom zewnętrznym w oparciu o zawarte umowy. Odpowiedzialność za działania wykonywane w obszarze realizacji kontroli krzyżowych programu przez instytucje systemu wdrażania lub podmioty zewnętrzne ponosi Instytucja Zarządzająca. 
Tabela 1. System wykrywania podwójnego finansowania wydatków w projektach unijnych

\begin{tabular}{|c|c|c|c|}
\hline \multicolumn{2}{|c|}{ Typ (obszar) kontroli } & $\begin{array}{c}\text { Podmiot } \\
\text { kontrolujacy }\end{array}$ & Podstawa weryfikacji \\
\hline \multirow{5}{*}{$\begin{array}{l}\text { Kontrola } \\
\text { krzyżowa } \\
\text { programu }\end{array}$} & $\begin{array}{l}\text { Weryfikacja wniosku } \\
\text { o dofinansowanie }\end{array}$ & \multirow{5}{*}{$\begin{array}{l}\text { Instytucja } \\
\text { Zarządzająca } \\
\text { (IZ) }\end{array}$} & $\begin{array}{c}\text { Oświadczenie wnioskodawcy / } \\
\text { dane o innych projektach } \\
\text { wnioskodawcy }\end{array}$ \\
\hline & $\begin{array}{c}\text { Weryfikacja wniosku } \\
\text { o płatność }\end{array}$ & & $\begin{array}{l}\text { Oświadczenie beneficjenta, } \\
\text { wniosek o płatność wraz } \\
\text { z kopiami dokumentów } \\
\text { księgowych }\end{array}$ \\
\hline & $\begin{array}{l}\text { Kontrola na miejscu } \\
\text { realizacji projektu }\end{array}$ & & $\begin{array}{l}\text { Oryginały dokumentów księ- } \\
\text { gowych związanych } \\
\text { z realizowanym projektem }\end{array}$ \\
\hline & $\begin{array}{c}\text { Kontrola krzyżowa } \\
\text { horyzontalna z projektami } \\
\text { PROW 07-13 i/lub PO } \\
\text { RYBY 07-13 }\end{array}$ & & $\begin{array}{l}\text { Oryginały dokumentów księ- } \\
\text { gowych związanych } \\
\text { z realizowanym projektem }\end{array}$ \\
\hline & $\begin{array}{c}\text { Kontrola krzyżowa } \\
\text { prowadzona na } \\
\text { dokumentach rozliczonych } \\
\text { przez beneficjentów } \\
\text { realizujących min. } 2 \\
\text { projekty w programie }\end{array}$ & & $\begin{array}{l}\text { Dane z KSI SIMIK 07-13 } \\
\text { lub LSI }{ }^{3}\end{array}$ \\
\hline \multicolumn{2}{|c|}{ Kontrola krzyżowa horyzontalna } & \multirow{2}{*}{$\begin{array}{l}\text { Instytucja Ko- } \\
\text { ordynująca } \\
\text { Narodowe Stra- } \\
\text { tegiczne Ramy } \\
\text { Odniesienia } \\
\text { (IK NSRO) } \\
\end{array}$} & Dane z KSI SIMIK 07-13 \\
\hline \multicolumn{2}{|c|}{ Kontrola krzyżowa międzyokresowa } & & $\begin{array}{c}\text { Dane z KSI SIMIK 07-13 } \\
\text { oraz z SIMIK 04-06 }\end{array}$ \\
\hline
\end{tabular}

Źródło: Opracowanie własne

\section{Weryfikacja przestrzegania zakazu podwójnego finansowania na etapie aplikowania o środki unijne, w trakcie rozliczania wydatków przez beneficjentów oraz w toku kontroli projektu na miejscu}

Pierwszym z instrumentów umożliwiających wykrycie zamiaru podwójnego finansowania wydatków jest weryfikacja dokumentacji aplikacyjnej złożonej przez wnioskodawcę. Działanie ma charakter prewencyjny, ponieważ uniemożliwia zawarcie umowy o dofinansowanie, której zakres rzeczowy pokrywałby się ze złożonym bądź realizowanym przez ten sam podmiot projektem unijnym. Przedmiotowa weryfikacja dokonywana jest w oparciu o złożone oświadczenie, które stanowi

${ }^{3}$ Lokalny System Informatyczny - system wdrożony przez instytucję zaangażowaną we wdrażanie funduszy unijnych na potrzeby realizacji powierzonych zadań.

${ }^{4}$ System Informatycznego Monitoringu i Kontroli Finansowej Funduszy Strukturalnych i Funduszu Spójności wdrożony dla okresu programowania 2004-2006. 
element wniosku o dofinansowanie (lub załącznik do wniosku). W przypadku Programu Operacyjnego Innowacyjna Gospodarka (PO IG) oświadczenie było elementem wniosku o dofinansowanie. Na etapie aplikowania o wsparcie unijne beneficjent deklarował, że w przypadku otrzymania dofinansowania na realizację projektu nie naruszy zasady zakazu podwójnego finansowania, oznaczającej niedozwolone zrefundowanie całkowite lub częściowe danego wydatku dwa razy ze środków publicznych (wspólnotowych lub krajowych). We wniosku o dofinansowanie wnioskodawca składał również oświadczenie dotyczące możliwości lub braku prawnej możliwości odzyskania/odliczenia kosztu podatku VAT poniesionego $\mathrm{w}$ związku z realizacją działań objętych wnioskiem ${ }^{5}$. Powyższe dokumenty stanowiły podstawę weryfikacji naruszenia zakazu podwójnego finansowania na etapie aplikowania o dofinansowanie.

Źródłem informacji o możliwości wystąpienia podwójnego finansowania w analizowanym obszarze mogą być również, zgromadzone przez instytucję udzielającą wsparcia, informacje odnośnie realizowanych lub zrealizowanych projektów wnioskodawcy, którego wniosek o dofinansowanie podlega ocenie. Tworzenie baz informacyjnych zawierających dane o zakresie rzeczowym wszystkich wybranych do dofinansowania projektów wydaje się być dobrym narzędziem umożliwiającym wykrycie tożsamych zakresów rzeczowych projektów jednego beneficjenta, jednakże w perspektywie finansowej 2007-2013 nie było stosowane na szerszą skalę.

Drugim instrumentem umożliwiającym wykrycie podwójnego finansowania jest wniosek o płatność. Przedmiotowy dokument składany jest przez beneficjentów cyklicznie (nie rzadziej niż raz na trzy miesiące) przez cały okres realizacji projektu. Wniosek beneficjenta o płatność jest podstawowym instrumentem monitorowania prawidłowości realizacji projektu. Zawiera informacje o postępie rzeczowym i finansowym przedsięwzięcia objętego wsparciem (Rydzewska-Włodarczyk 2011, s. 301-302). Do wniosku beneficjent załącza kopie dokumentów potwierdzających poniesione $\mathrm{w}$ danym okresie sprawozdawczym wydatki kwalifikowalne, w tym przede wszystkim: dokumenty księgowych wraz z potwierdzeniami zapłaty (wyciąg bankowy, dokument $\mathrm{KP}, \mathrm{KW}$ i raport kasowy ${ }^{6}$ ), dokumentację potwierdzającą przeprowadzenie rozeznania rynku, przetargu publicznego lub postępowania ofertowego ${ }^{7}$, zamówienia oraz umowy z dostawcami/wykonawcami, protokoły zdawczo-odbiorcze potwierdzające odbiór prac/dostaw/robót budowlanych oraz dokumenty potwierdzające ujęcie $\mathrm{w}$ ewidencji księgowej dokonanych zakupów ${ }^{8}$.

\footnotetext{
5 Wzór wniosku o dofinansowania realizacji projektu w ramach osi priorytetowej 4, działania 4.4 Inwestycje o wysokim potencjale rozwoju (http://poig.parp.gov.pl/files/74/108/203/650/712/17920.pdf).

${ }^{6} \mathrm{~W}$ przypadku, w którym $\mathrm{w}$ danym programie pomocowym dopuszczono możliwość dokonywania płatności gotówkowych. Dokument KW wraz z raportem kasowym przedkłada beneficjent prowadzący pełną księgowość.

${ }^{7}$ Dotyczy beneficjentów niepodlegających przepisom ustawy Prawo zamówień publicznych.

${ }^{8} \mathrm{~W}$ zależności od formy rozliczania dochodów, tj. prowadzenie pełnej lub uproszczonej księgowości, beneficjenci załączają do wniosku o płatność inne dokumenty, np. potwierdzeniem przyjęcia do ewidencji środków trwałych lub wartości niematerialnych i prawnych w przypadku prowadzenia pełnej księgowości jest protokół odbioru technicznego (OT), podczas gdy w przypadku uproszczonej księgowości - ewidencja środków trwałych i wartości niematerialnych i prawnych.
} 
W ramach każdego sprawozdania z realizacji projektu beneficjent składa oświadczenie o braku podwójnego finansowania pod rygorem odpowiedzialności karnej wynikającej z art. 297 Kodeksu karnego, dotyczącej poświadczania nieprawdy co do okoliczności mających znaczenie prawne. W trakcie oceny wniosku o płatność weryfikacja możliwości wystąpienia podwójnego finansowania dokonywana jest w oparciu o kopie dokumentów księgowych złożonych przez beneficjenta. Kontrola przeprowadzana jest pod kątem wystąpienia na dokumentach potwierdzających poniesione wydatki informacji świadczących o współfinansowaniu projektu z innych źródeł publicznych. Zgodnie z obowiązkiem nałożonym przez Komisję Europejską na beneficjentów programów operacyjnych każdy biorca pomocy wspólnotowej ma obowiązek umieszczania na dowodach księgowych dokumentujących poniesione wydatki kwalifikowalne informacji o źródłach finansowania realizowanego projektu. Powyższe oznaczenie w przypadku realizacji projektów inwestycyjnych przyjmuje postać: „Projekt jest współfinansowany ze środków Europejskiego Funduszu Rozwoju Regionalnego oraz ze środków budżetu państwa [...]"9.

$\mathrm{Na}$ etapie rozliczania projektu możliwość wystąpienia podwójnego finansowania wydatków weryfikowana jest również w przypadku dokonania przez beneficjenta zakupu używanego środka trwałego. Na realizatorach projektów unijnych nabywających używane środki trwałe ciąży obowiązek przedłożenia oświadczenia sprzedawcy, potwierdzającego, że w okresie ostatnich 7 lat poprzedzających datę sprzedaży sprzęt będący przedmiotem transakcji nie został zakupiony z wykorzystaniem środków publicznych krajowych lub pochodzących z funduszy Unii Europejskiej (MRR 2010, s. 29).

Weryfikacja wydatków rozliczonych w ramach projektu przeprowadzana jest obligatoryjnie $\mathrm{w}$ toku kontroli na miejscu realizacji projektu. W ramach prowadzonych działań zespół kontrolujący weryfikuje m.in. zgodność kserokopii dokumentów księgowych załączanych do wniosków o płatność z oryginałami posiadanymi przez beneficjenta (Majchrzak, Rydzewska-Włodarczyk 2013, s. 183-184). Powyższe porównanie pozwala na stwierdzenie, czy na oryginałach dokumentów księgowych znajdują się informacje o finansowaniu towarów/usług lub robót z innych źródeł publicznych.

\section{Kontrola krzyżowa horyzontalna z projektami PROW i PO RYBY 07-13}

Obowiązek realizacji kontroli krzyżowych horyzontalnych z projektami finansowanymi ze środków PO RYBY 07-13 i PROW 07-13 nakładały na Instytucje Zarządzające programami operacyjnymi wytyczne Ministerstwa Infrastruktury i Rozwoju w zakresie procesu kontroli w ramach obowiązków Instytucji Zarządzających Programami Operacyjnymi. Przedmiotowym kontrolom podlegali beneficjenci realizujący projekty w ramach krajowych i regionalnych programów operacyjnych NSRO oraz Programu Operacyjnego Zrównoważony Rozwój Sektora Rybołówstwa i Nad-

\footnotetext{
${ }^{9}$ Szerzej: Zasady opisywania faktur lub innych dokumentów o równoważnej wartości dowodowej (https://poig.parp.gov.pl/files/74/108/255/6109.pdf).
} 
brzeżnych Obszarów Rybackich 2007-2013 ${ }^{10}$ (tj. PO RYBY) i/lub Programu Rozwoju Obszarów Wiejskich na lata 2007-2013 ${ }^{11}$ (tj. PROW 07-13).

Kontrole krzyżowe horyzontalne mogły być realizowane zza biurka w oparciu o zestawienia dokumentów rozliczonych w ramach współfinansowanych projektów w trakcie weryfikacji każdego wniosku o płatność, na zakończenie realizacji projektu lub w trakcie kontroli przedsięwzięcia na miejscu realizacji. W przypadku prowadzenia kontroli krzyżowych na dokumentach rozliczonych w ramach PO NSRO oraz PROW 07-13 i/lub PO RYBY 07-13 weryfikacji w każdym kwartale podlegały, zgodnie z pkt 7.3.4 oraz 7.4.4 ww. wytycznych (Ministerstwo Infrastruktury i Rozwoju 2014, s. 26-27), dane dotyczące wszystkich beneficjentów realizujących projekty równolegle. W przypadku krzyżowej weryfikacji wystąpienia podwójnego finansowania $\mathrm{W}$ trakcie realizacji kontroli projektów na miejscu fakt realizacji projektu w ramach PROW 07-13 i/lub PO RYBY 07-13, zgodnie z pkt 7.3.5 oraz 7.4.5 wytycznych horyzontalnych (Ministerstwo Infrastruktury i Rozwoju 2014, s. 26), był jednym z czynników ryzyka metodologii doboru próby projektów do kontroli. Stwierdzenie uzasadnionego podejrzenia wystąpienia podwójnego finansowania obliguje Instytucję Zarządzającą NSRO do wystąpienia, do właściwej Instytucji Wdrażającej PROW 07-13 lub PO RYBY 07-13, o przekazanie poświadczonych za zgodność z oryginałem kopii dokumentów księgowych rozliczonych w ramach współfinansowanego projektu. W przypadku potwierdzenia wystąpienia podwójnego finansowania informacja na temat dokonanych ustaleń przekazywana jest do instytucji, która udostępniła dokumenty, agencji płatniczej PROW 07-13 i/lub PO RYBY 07-13, instytucji certyfikującej oraz IZ NSRO ${ }^{12}$.

\section{Kontrola krzyżowa programu operacyjnego}

Kontrola krzyżowa programu realizowana jest przez każdą Instytucję Zarządzającą. Kontroli podlegają beneficjenci realizujący minimum dwa projekty w ramach jednego programu operacyjnego. Dane niezbędne do przeprowadzenia przedmio-

\footnotetext{
${ }^{10}$ Program finansowany w latach 2007-2013 ze środków Europejskiego Funduszu Rybackiego oraz budżetu państwa. Instytucją Zarządzającą przedmiotowym programem jest minister właściwy ds. rybołówstwa. Program obejmował 5 osi priorytetowych. Budżet programu wyniósł $870 \mathrm{mln}$ euro. Osie 1-3 programu wdrażała Agencja Restrukturyzacji i Modernizacji Rolnictwa (ARiMR), a 4 oś priorytetową - samorządy województw. Szerzej: (http://www.minrol.gov.pl/...).

${ }^{11}$ Program finansowany w latach 2007-2013 ze środków Europejskiego Funduszu Rolnego na rzecz Rozwoju Obszarów Wiejskich oraz budżetu państwa. Instytucją Zarządzającą programem jest Ministerstwo Rolnictwa i Rozwoju Wsi. Program obejmował dwadzieścia trzy działania wdrażane w ramach czterech osi priorytetowych. W ramach PROW 07-13 piętnaście działań wdrażała Agencja Restrukturyzacji i Modernizacji Rolnictwa (ARiMR), sześć działań wdrażały samorządy wojewódzkie oraz po jednym Agencja Rynku Rolnego (ARR) i Fundacja Programów Pomocy dla Rolnictwa (FAPA). Szerzej: (http://www.arimr.gov.pl/...).

${ }^{12}$ Informacja o wykryciu podwójnego finansowania przekazywana jest do IZ NSRO w sytuacji, kiedy kontrola krzyżowa realizowana była przez Instytucję Podległą (IP/IW). Dodatkowo, zgodnie z pkt 7.4.9 wytycznych horyzontalnych w zakresie kontroli, w przypadku PO RYBY 07-13 informacja o wykryciu podwójnego finansowania wydatków przekazywana jest również do IZ PO RYBY, jeśli IZ PO RYBY nie była instytucją udostępniającą kopie dokumentów księgowych na potrzeby przeprowadzenia kontroli krzyżowej.
} 
towej kontroli, w perspektywie finansowej 2007-2013, generowane były z systemu KSI SIMIK 07-13. Kontrola, zgodnie z pkt 7.1.2 wytycznych horyzontalnych (MIiR 2014, s. 22), mogła być prowadzona w trakcie weryfikacji każdego wniosku beneficjenta o płatność, na losowanej w każdym kwartale próbie 5\% beneficjentów realizujących więcej niż jeden projekt $\mathrm{w}$ ramach programu lub na etapie wprowadzania danych do LSI (w przypadku stwierdzenia rozliczania przez jednego beneficjenta tych samych dokumentów księgowych w ramach kilku projektów). Kontroli krzyżowej programu (prowadzonej na próbie) mógł podlegać beneficjent, którego NIP nie został wylosowany do kontroli w danym kwartale w przypadku wystapienia podejrzenia przedkładania do dofinansowania $\mathrm{w}$ ramach różnych projektów tych samych dokumentów księgowych (wydatków). W przypadku stwierdzenia podejrzenia wystąpienia podwójnego finansowania wydatków w ramach jednego programu operacyjnego Instytucja Zarządzająca przeprowadzała weryfikacje oryginałów bądź kopii dokumentów rozliczonych przez beneficjenta $\mathrm{w}$ ramach projektów objętych kontrolą krzyżową lub podejmowała decyzję o realizacji kontroli projektów na miejscu. Podwójne finansowanie wydatków występowało wówczas, kiedy suma wydatków kwalifikowalnych poniesionych na podstawie jednego dokumentu księgowego przekraczała wartość wydatków kwalifikowalnych rozliczonego dowodu. Informacja o wykryciu podwójnego finansowania wydatków przekazywana była do instytucji certyfikującej.

\section{Kontrola krzyżowa horyzontalna i międzyokresowa}

Obowiązek okresowego przeprowadzania kontroli krzyżowych horyzontalnych oraz międzyokresowych ${ }^{13}$ spoczywa na IK NSRO. Zgodnie z pkt 7.2.1 wytycznych w zakresie kontroli (MIiR 2014, s. 24) przedmiotowe kontrole przeprowadzane są przez pracowników Departamentu Koordynacji Wdrażania Funduszy Unii Europejskiej lub podmiot zewnętrzny, któremu w drodze przetargu publicznego zlecono przeprowadzenie czynności kontrolnych. Celem kontroli krzyżowej horyzontalnej jest wykrycie i wyeliminowanie podwójnego finansowania wydatków przez beneficjentów realizujących więcej niż jeden projekt $\mathrm{w}$ ramach różnych programów operacyjnych jednej perspektywy finansowej. Przedmiotowa weryfikacja przeprowadzana była w oparciu o zestawienia zatwierdzonych do dofinansowania dokumentów księgowych zarejestrowane przez poszczególne instytucje systemu wdrażania programów operacyjnych w KSI SIMIK 07-13. Kontroli podlegała w każdym kwartale losowo wybrana próba co najmniej $5 \%$ beneficjentów NSRO.

Celem kontroli międzyokresowej jest wykrycie i wyeliminowanie podwójnego finansowania tych samych wydatków przez beneficjentów, którzy realizowali więcej niż jeden projekt $w$ ramach dwóch perspektyw finansowych (2004-2006 i 2007-2013 lub 2007-2013 i 2014-2020) i przedłożyli do rozliczenia wnioski o płatność w czasie nakładania się dwóch okresów kwalifikowalności wydatków. Przedmiotowa kontrola była realizowana w każdym półroczu na próbie co najmniej 5\% beneficjentów. Kontroli krzyżowej horyzontalnej i międzyokresowej mógł

${ }^{13}$ Bez kontroli krzyżowych z projektami PO RYBY 07-13 i PROW 07-13. 
podlegać beneficjent, którego NIP nie został wylosowany w próbie w danym okresie weryfikacji w przypadku wystąpienia podejrzenia przedkładania do dofinansowania $\mathrm{w}$ ramach różnych programów/perspektyw finansowych tych samych wydatków. Podobnie jak miało to miejsce w przypadku kontroli krzyżowych horyzontalnych z projektami PROW 07-13 i PO RYBY 07-13, w sytuacji podejrzenia wystąpienia podwójnego finansowania wydatków IK NSRO występowała do właściwych Instytucji Zarządzających o przedłożenie do weryfikacji kopii rozliczonych dowodów księgowych. W przypadku potwierdzenia wystąpienia podwójnego finansowania tego samego wydatku IK NSRO niezwłocznie zawiadamiała o tym fakcie właściwą Instytucję Zarządzającą.

\section{Postępowanie w przypadku wykrycia podwójnego finansowania}

Stwierdzenie wystąpienia podwójnego finansowania wydatków w toku kontroli krzyżowej skutkuje niekwalifikowalnością wydatków i koniecznością zwrotu dofinansowania. W tym celu instytucja będąca stroną umowy o dofinansowanie, wzywa beneficjenta do zwrotu nieprawidłowo wydatkowanych środków w trybie art. 207 ust. 1 ustawy o finansach publicznych (Kowalski 2014, s. 147). Kwota do zwrotu rejestrowana jest w systemie KSI SIMIK 07-13.

W świetle ww. przepisu środki przeznaczone na realizację programów finansowanych $\mathrm{z}$ udziałem funduszy europejskich, wydatkowane niezgodnie $\mathrm{z}$ przeznaczeniem, wykorzystane $\mathrm{z}$ naruszeniem procedur, o których mowa w art. 184 ustawy o finansach publicznych lub pobrane nienależnie lub w nadmiernej wysokości, podlegają zwrotowi wraz z odsetkami w wysokości jak dla zaległości podatkowych w terminie 14 dni od dnia doręczenia ostatecznej decyzji w przedmiocie zwrotu (Ustawa z dnia 27 sierpnia 2009 r. ...; Szymański 2010, s. 116-117). Alternatywą dla powyższego rozwiązania jest wyrażenie zgody przez beneficjenta na pomniejszenie kolejnej transzy dofinansowania o kwotę przypadającą do zwrotu ${ }^{14}$. Powyższe potrącenie dokonywane jest na etapie wypłaty kolejnej transzy dofinansowania. W przypadku niedokonania zwrotu we wskazanym terminie instytucja, która wezwała beneficjenta do zwrotu, wszczyna postępowanie administracyjne. Po rozpoznaniu sprawy wydawana jest decyzja administracyjna. W przypadku niedokonania zwrotu dofinansowania wszczynana jest egzekucja administracyjna w celu przymusowego ściągnięcia należności (Urząd Marszałkowski Województwa Zachodniopomorskiego 2015, s. 6-7).

Od wydanej decyzji administracyjnej beneficjentowi przysługuje odwołanie, które składane jest za pośrednictwem instytucji wydającej decyzję w pierwszej instancji ${ }^{15}$. Odwołanie należy wnieść $\mathrm{w}$ terminie 14 dni od daty doręczenia decyzji. Organ odwoławczy wydaje decyzję, w której utrzymuje w mocy zaskarżoną decyzję, uchyla zaskarżoną decyzję w całości lub w części albo umarza postępowanie odwoławcze (MRR 2011, s. 24). Od decyzji wydanej w drugiej instancji stronie

\footnotetext{
${ }^{14}$ Kwota uwzględniana jest w zleceniu płatności kierowanym do Banku Gospodarstwa Krajowego zgodnie z art. 207 ust 2 Ustawy z dnia 27 sierpnia 2009 r. o finansach publicznych.

15 Jeśli jest to Instytucja Zarządzająca, beneficjent ma prawo wystąpić z wnioskiem o ponowne rozpatrzenie sprawy.
} 
przysługuje środek odwoławczy w postaci możliwości wniesienia skargi do Wojewódzkiego Sądu Administracyjnego za pośrednictwem Instytucji Zarządzającej. Od wyroku Wojewódzkiego Sądu Administracyjnego stronie przysługuje możliwość wniesienia skargi kasacyjnej do Naczelnego Sądu Administracyjnego.

Potwierdzone przez właściwą instytucję podwójne finansowanie wydatków na gruncie przepisów unijnych spełnia przesłanki nieprawidłowości. Zgodnie $\mathrm{z}$ art. 2 pkt 7 Rozporządzenia Rady (WE) 1083/2006 za nieprawidłowość należy uważać jakiekolwiek naruszenie przepisu prawa wspólnotowego wynikające z działania lub zaniechania podmiotu gospodarczego, które powoduje lub mogłoby spowodować szkodę w budżecie ogólnym Unii Europejskiej w drodze finansowania nieuzasadnionego wydatku z budżetu ogólnego. Warto podkreślić, że z nieprawidłowością mamy do czynienia również $\mathrm{w}$ sytuacji naruszenia przepisów prawa krajowego, kiedy w danym obszarze jest ono bardziej restrykcyjne niż przepisy unijne. Stwierdzenie wystąpienia wydatków niekwalifikowalnych w projekcie wiąże się z koniecznością zgłoszenia nieprawidłowości, zgodnie $\mathrm{z}$ obowiązującą procedurą ${ }^{16}$, w formie raportu o nieprawidłowości podlegającej raportowaniu do Komisji Europejskiej lub kwartalnego zestawienia nieprawidłowości niepodlegających zgłoszeniu. Podstawę do zaklasyfikowania danego naruszenia do właściwej kategorii stanowi pkt 5.3.3 Wytyczne Ministra Rozwoju Regionalnego $w$ zakresie sposobu postępowania $w$ razie wykrywania nieprawidtowości $w$ wykorzystaniu funduszy strukturalnych i Funduszu Spójności w okresie programowania 2007-2013 (MRR 2008, s. 15; Karwatowicz, Odachowski 2009, s. 118-119). Po dokonaniu zwrotu nieprawidłowo wydatkowanych środków przez beneficjenta oraz wycofaniu ich z rozliczeń z Komisją Europejską właściwa instytucja raportująca zamyka nieprawidłowość.

\section{Wykrywalność podwójnego finansowania wydatków na przykładzie Programu Operacyjnego Innowacyjna Gospodarka}

PO IG wdrażany był w perspektywie finansowej 2007-2013 przez Departament Wsparcia Programów Innowacji i Rozwoju Ministerstwa Rozwoju ${ }^{17}$ pełniący funkcję Instytucji Zarządzającej, trzy Instytucje Pośredniczące (Ministerstwo Gospodarki, Ministerstwo Cyfryzacji i Administracji oraz Narodowe Centrum Badań i Rozwoju) oraz pięć Instytucji Wdrażających (Polską Agencję Rozwoju Przedsiębiorczości, Bank Gospodarstwa Krajowego, Centrum Projektów Polska Cyfrowa, Polską Organizację Turystyczną oraz Ośrodek Przetwarzania Informacji - Państwowy Instytut Badawczy). W okresie wdrażania PO IG instytucje zaangażowane w jego realizację zrealizowały poniższe działania mające na celu wykrycie podwójnego finansowania wydatków:

\footnotetext{
${ }^{16}$ Wytyczne Ministra Rozwoju Regionalnego w zakresie sposobu postępowania w razie wykrywania nieprawidłowości w wykorzystaniu funduszy strukturalnych i Funduszu Spójności w okresie programowania 2007-2013.

${ }^{17}$ Wcześniej Departament Konkurencyjności i Innowacyjności (DKI) Ministerstwa Rozwoju.
} 
- 380 kontroli krzyżowych horyzontalnych z projektami PROW 07-13 oraz PO RYBY 07-13. Kontrole przeprowadzone zostały przez pracowników instytucji wdrażających i pośredniczących PO IG w trakcie kontroli projektów na miejscu. W ramach przeprowadzonych kontroli nie stwierdzono podwójnego finansowania wydatków (MR 2017, s. 130).

- 4283 kontrole krzyżowe programu operacyjnego (415 kontroli przeprowadziła Instytucja Zarządzająca, a 3868 kontroli zewnętrzny wykonawca wybrany w trybie zamówienia publicznego). Kontrolami objęto beneficjentów realizujących minimum 2 projekty finansowane ze środków PO IG. Czynności kontrolne realizowane były na podstawie danych wygenerowanych z KSI SIMIK 07-13. W toku weryfikacji wykryto 12 przypadków podwójnego finansowania wydatków. Na wniosek Instytucji Zarządzającej właściwe instytucje nadzorujące realizacje projektów, w których stwierdzono wystąpienie nieprawidłowości, podjęły stosowne działania naprawcze (MR 2017, s. 130-131).

- 12466 kontroli planowych i doraźnych projektów na miejscu realizacji oraz 1666 kontroli trwałości. Kontrole przeprowadzone zostały przez instytucje będące stronami zawartych umów o dofinansowanie. W ramach ww. kontroli wykryto 3 przypadki podwójnego finansowania wydatków (MR 2017, s. 133).

W toku weryfikacji wniosków beneficjentów o płatność lub kontroli dokumentacji projektowej wykryto 11 przypadków naruszenia zakazu podwójnego finansowania. Dodatkowo stwierdzono 6 przypadków podwójnego finansowania w toku weryfikacji informacji przekazanych przez beneficjentów (pisemne zgłoszenie realizatora projektu o omyłkowym - podwójnym rozliczeniu tego samego wydat$\mathrm{ku})^{18}$. W toku kontroli krzyżowych horyzontalnych i międzyokresowych przeprowadzonych przez Instytucję Koordynującą Narodowe Strategiczne Ramy Odniesienia wykryto 1 nieprawidłowość ${ }^{19}$.

Powyższe informacje wskazują, że najskuteczniejszymi instrumentami wykrywania podwójnego finansowania wydatków w ramach PO IG, w minionej perspektywie finansowej, były kontrole krzyżowe programu realizowane przez Instytucję Zarządzającą (lub na jej zlecenie), weryfikacja wniosków o płatność oraz kontrola dokumentów.

W celu ustalenia obszarów najczęstszego występowania podwójnego finansowania wydatków przez biorców pomocy wspólnotowej oraz prawdopodobnych przyczyn powstawania nieprawidłowości w kwietniu 2017 roku przeprowadzono 2 indywidualne wywiady pogłębione z pracownikami Wydziału Kontroli Departamentu Programów Wsparcia Innowacji i Rozwoju (DIR) Ministerstwa Rozwoju, tj. Instytucji Zarządzającej PO IG. W toku przeprowadzonych wywiadów ustalono, że nieprawidłowości $\mathrm{w}$ obszarze naruszenia zakazu podwójnego finansowania dotyczą najczęściej wynagrodzeń pracowników zatrudnionych do realizacji projektów unijnych oraz niewielkiej wartości faktur zakupowych. W większości wykrytych

\footnotetext{
${ }^{18}$ Według danych Departamentu Programów Wsparcia Innowacji i Rozwoju Ministerstwa Rozwoju (stan na IV kw. 2016 r.).

${ }^{19}$ Według danych Departamentu Programów Wsparcia Innowacji i Rozwoju Ministerstwa Rozwoju (stan na IV kw. 2016 r.).
} 
przypadków podwójne finansowanie nie było związane $\mathrm{z}$ dwukrotnym przedstawieniem do rozliczenia tych samych dowodów księgowych w pełnej wysokości (np. kwalifikowaniem w ramach kilku projektów tej samej faktury w pełnej wysokości), a jedynie częściowym nakładaniem się wydatków kwalifikowalnych dokumentu księgowego rozliczonego $\mathrm{w}$ ramach kilku współfinansowanych przedsięwzięć (np. kwota netto faktury wynosząca 1000 PLN została rozliczona w dwóch projektach po 600 PLN w każdym, co oznacza podwójne finansowanie wydatków w wysokości 200 PLN).

Typy błędów, niewielkie wartości podwójnie rozliczanych dokumentów księgowych oraz sporadyczność występowania naruszeń wskazują na przypadkowy charakter popełnianych przez beneficjentów uchybień, których przyczyny można upatrywać w lukach systemu monitorowania finansowego projektów oraz ewidencji księgowej. Analiza wyników zrealizowanych kontroli nasuwa pytanie o racjonalność przeprowadzania przedmiotowych weryfikacji. O ile weryfikacja wystąpienia podwójnego finansowania jest jednym $\mathrm{z}$ elementów kontroli wniosku o płatność oraz kontroli projektu na miejscu, to kontrola krzyżowa programu operacyjnego prowadzona jest wyłącznie w celu wykrycia i wyeliminowania podwójnego finansowania wydatków. Mając na uwadze stosunek liczby wykrytych przypadków podwójnego finansowania (12 przypadków) do liczby przeprowadzonych kontroli (4283 weryfikcje) oraz niewielkie wartości wykrytych nieprawidłowości w ramach PO IG ${ }^{20} \mathrm{w}$ perspektywie finansowej 2014-2020, warto przeanalizować minimalną wielkość próby beneficjentów podlegających kontroli, tak aby zapewnić racjonalność podejmowanych działań $\mathrm{w}$ przedmiotowym obszarze. Wszystko wskazuje na to, że w trwającej perspektywie finansowej Departament Koordynacji Wdrażania Funduszy Unii Europejskiej (IK UP) dopuści możliwość samodzielnego określania wielkości próby beneficjentów podlegających kontrolom krzyżowym programów operacyjnych. Konsultowany od listopada 2017 r. Projekt zmian Wytycznych $w$ zakresie kontroli realizacji programów operacyjnych na lata 2014 -2020 w ust. 3 podrozdziału 5.3 znosi dotychczas obowiązującą minimalną $(5 \%)$ wielkość próby beneficjentów podlegających kwartalnej kontroli krzyżowej. W miejsce powyższego uregulowania Projekt zmian Wytycznych $w$ zakresie kontroli realizacji programów operacyjnych na lata 2014-2020 proponuje wprowadzić zapis upoważniający Instytucje Zarządzające do określenia minimalnej wielkości próby na poziomie dającym racjonalne zapewnienie, że wydatki ujęte $\mathrm{w}$ zestawieniu wydatków do Komisji Europejskiej nie zostały podwójnie sfinansowane (https://www.funduszeeuropejskie.gov.p1/...). Powyższą propozycję zmiany zapisów przedmiotowych wytycznych, w świetle przytoczonych danych statystycznych, należy ocenić pozytywnie.

Wykrycie podwójnego finansowania wydatków przez beneficjenta realizującego równolegle kilka projektów powinno nastąpić w toku realizacji procesu monitoringu finansowego. Niezidentyfikowanie podwójnego kwalifikowania tych samych wydatków świadczy o nieprawidłowym zarządzaniu projektem. Mając na uwadze powyższe, zasadne wydaje się wykorzystywanie przez beneficjentów realizujących

${ }^{20}$ Informacja uzyskana w toku indywidualnych wywiadów pogłębionych. 
kilka projektów równocześnie (obok budżetów/harmonogramów finansowych) dodatkowego narzędzia monitorującego wydatki kwalifikowalne rozliczane w ramach wszystkich realizowanych przedsięwzięć finansowanych ze środków publicznych. Bieżące ewidencjonowanie w ww. zestawieniu wszystkich planowanych do rozliczenia dokumentów księgowych umożliwi wykrycie podwójnego finansowania przed złożeniem wniosków o płatność, a zatem uniknięcie wystąpienia nieprawidłowości.

\section{Podsumowanie}

Szeroki katalog narzędzi wykrywania podwójnego finansowania wdrożony $\mathrm{w}$ ramach regionalnych i krajowych programów operacyjnych w perspektywie finansowej 2007-2013 zapewnił instytucjom zaangażowanym w proces wdrażania polityki spójności w Polsce możliwość realizacji działań kontrolnych na wszystkich etapach realizacji projektów. Przedstawione w artykule dane dotyczące wykrywalności naruszeń zakazu podwójnego finansowania świadczą o marginalnym charakterze nieprawidłowości popełnianych w przedmiotowym obszarze oraz ich przypadkowym charakterze.

Zaplanowane do wdrażania na szeroką skalę w okresie programowania 2014-2020 instrumenty finansowe $\mathrm{w}$ połączeniu $\mathrm{z}$ dopuszczoną na mocy art. 37 ust. 8 Rozporządzenia Ogólnego 1303/2013 z dnia 17 grudnia 2013 r. możliwością łączenia $w$ ramach jednej inwestycji pomocy rewolwingowej (np. preferencyjnej pożyczki) i innych form wsparcia (np. dotacji) wymuszą na instytucjach wdrażających fundusze unijne opracowanie nowych narzędzi weryfikacji wystąpienia podwójnego finansowania na dużo większą skalę. Realizowane kontrole przestrzegania zakazu podwójnego finansowania będą musiały uwzględniać możliwość wystąpienia nieprawidłowości polegających na udzieleniu kilku form wsparcia na rzecz jednej operacji, co spowoduje przekroczenie dopuszczalnych limitów pomocy (np. wykorzystanie instrumentów finansowych na prefinansowanie dotacji bądź wydatkowanie dotacji na spłatę wsparcia otrzymanego $\mathrm{z}$ instrumentu finansowego). Prawdopodobieństwo wystąpienia ww. kategorii naruszeń jest duże w związku z niewielkim doświadczeniem beneficjentów w zakresie wykorzystywania instrumentów finansowych oraz łączenia ich z innymi kategoriami pomocy. Skutecznym działaniem prewencyjnym zapobiegającym wystąpieniu nieprawidłowości mogłaby być zrealizowana na szeroką skalę kampania medialna, dedykowana potencjalnym biorcom wsparcia zwrotnego, informująca o możliwościach i ograniczeniach finansowania inwestycji za pośrednictwem instrumentów zwrotnych. Niestety, od początku uruchomienia perspektywy finansowej 2014-2020 do chwili obecnej skuteczne działania informacyjne w przedmiotowym obszarze nie zostały zrealizowane. Pozostaje mieć nadzieję, że instytucje systemu wdrażania sprostają nowym zadaniom i w sposób należyty zapewnią ochronę interesów finansowych Unii Europejskiej oraz środków pochodzących z budżetu państwa. 


\section{Literatura}

1. Adamiecki K. (1985), O nauce organizacji, PWE, Warszawa.

2. Centrum Obsługi Przedsiębiorcy (2010), Podręcznik beneficjenta III Osi Priorytetowej Regionalnego Programu Operacyjnego Województwa Łódzkiego na lata 2007-2013, http://www.2007-2013.cop.lodzkie.pl/pliki/dokumenty_info_promo/podrecznikbeneficjenta.pdf (dostęp: 10.04.2017).

3. Domiter M., Marciszewska A. (2013), Zarzadzanie projektami unijnymi. Teoria i praktyka, Difin, Warszawa.

4. Duraj J. (2003), Controlling $w$ zarządzaniu przedsiębiorstwem, Wydawnictwo Naukowe Novum, Płock - Łódź.

5. Gnoiński J. (1967), Zasady organizacji i funkcjonowania systemu kontroli $w$ resorcie komunikacji, Ośrodek Badawczy Ekonomiki Transportu, Warszawa.

6. http://poig.parp.gov.pl/files/74/108/203/650/712/17920.pdf (dostęp: 09.04.2017).

7. http://www.arimr.gov.pl/programy-2002-2013/prow-2007-2013.html (dostęp: 10.04.2017).

8. http://www.minrol.gov.pl/Informacje-branzowe/Ministerstwo-Gospodarki-Morskiej-iZeglugi-Srodladowej/Pomoc-UE-dla-rybactwa/PO-RYBY-2007-2013 (dostęp: 11.04.2017).

9. https://poig.parp.gov.pl/files/74/108/255/6109.pdf (dostęp: 09.04.2017).

10. https://www.funduszeeuropejskie.gov.pl/strony/o-funduszach/dokumenty/projekt-zmianwytycznych-w-zakresie-kontroli-realizacji-programow-operacyjnych-na-lata-2014-2020/ (dostęp: 10.04.2017).

11. Łęgowik-Świącik S. (2012), Planowanie i kontrola $w$ zarządzaniu jednostkami gospodarczymi, „Zeszyty Naukowe Politechniki Częstochowskiej. Zarządzanie”, nr 6, s. 48-55.

12. Łukomska-Szarek J., Szczepaniak W. (2001), EU Funds as a Source of Financing of Regional and Local Development, [w:] Łukomska-Szarek J. (ed.), Budget Management in Local Self-Government Units, Sekcja Wydawnictw Wydziału Zarządzania Politechniki Częstochowskiej, Częstochowa, s. 58-73.

13. Kamiński D. (2008), Podstawy funkcjonowania systemu zarzadzania i kontroli wdrażania funduszy strukturalnych oraz Funduszu Spójności w ramach perspektywy 2007-2013, [w:] Lipińska A. (red.), Zarzadzanie, sprawozdawczość, kontrola, promocja i ewaluacja projektów dofinansowanych z funduszy unijnych, Twigger, Warszawa, s. 140-189.

14. Karwatowicz G., Odachowski J. (2009), Definicja legalna „nieprawidłowości” w kontekście funduszy strukturalnych i Funduszu Spójności, „Kontrola Państwowa”, R. 54, nr 4(327), s. $116-126$

15. KE (2006), Nowy okres programowania 2007-2013. Przewodnik po metodach ewaluacji: Wskaźniki monitoringu i ewaluacji. Dokument roboczy $n r$ 2, Komisja Europejska, sierpień 2006,http://www.archiwum.ewaluacja.gov.pl/ewaluacja_wstep/Documents/wskazniki170707. pdf (dostęp: 15.01.2018)

16. Kowalski D. (2014), Zwrot środków publicznych nieprawidłowo wykorzystywanych, „Państwo i Społeczeństwo", nr 4, s. 147-155.

17. Kuc B.R. (2009), Kontrola jako funkcja zarzadzania, Difin, Warszawa.

18. Majchrzak I., Rydzewska-Włodarczyk M. (2013), Control of Documentation Related to the Implementation of Projects Co-Funded by the European Union, ,Folia Pomeranea Universitatis Technologiae Stetinensis. Oeconomica", nr 306(73), s. 177-187.

19. MR (2017), Sprawozdanie końcowe z realizacji Programu Operacyjnego Innowacyjna Gospodarka 2007-2013, Ministerstwo Rozwoju, https://www.poig.2007-2013.gov.pl/Wiadomosci/ Strony/Innowacyjna_Gospodarka_efekty_podsumowania_220317.aspx (dostęp: 10.04.2017).

20. MRR (2008), Wytyczne w zakresie sposobu postepowania w razie wykrywania nieprawidtowości w wykorzystaniu funduszy strukturalnych i Funduszu Spójności w okresie programowania 2007-2013, Ministerstwo Rozwoju Regionalnego, https://www.funduszeeuropejskie.2007-2013. 
gov.pl/Dokumenty/wytycznepolskie/who/Documents/wytyczne/70205e2cf14946abb167e74 de6dab3f6Wytycznewzakresiesposobupostpowaniawraziewykrycian.pdf (dostęp: 10.04.2017).

21. MRR (2010), Krajowe wytyczne w zakresie kwalifikowania wydatków w ramach funduszy strukturalnych i Funduszu Spójności w okresie programowania 2007-2013, Ministerstwo Rozwoju Regionalnego, https://www.funduszeeuropejskie.2007-2013.gov.pl/Dokumenty/ wytycznepolskie/who/Documents/wytyczne/Wytyczne_horyzontalne_dot_kwalifikowania _wydatkow_w_ramach_fstrukturalnych_i_fspojnosci_2007_2013_14052010.pdf (dostęp: 10.04.2017)

22. MRR (2011), Zasady prowadzenia postępowań administracyjnych $i$ wydawania decyzji dot. zwrotu środków z funduszy UE, Ministerstwo Rozwoju Regionalnego, https://www.google.pl/ url?sa=t\&rct=j\&q=\&esrc=s\&source $=$ web\&cd $=6 \& c a d=r j a u a c t=8 \& v e d=0 a h U K E w j U 6 e i 5 j L$ vTAhUGFCwKHVE6DrkQFghBMAU\&url=https\%3A\%2F\%2Fwww.mos.gov.pl\%2Fg2\% 2Fbig\%2F2011_08\%2Fba2e7dd0f2b529f917e1220689eacbfb.ppt\&usg=AFQjCNEIvl80ShyCSE_ZKb6nfDUYnQ-UA (dostęp: 10.04.2017).

23. MIiR (2014), Krajowe wytyczne w zakresie procesu kontroli w ramach obowiazków Instytucji Zarzadzajacej Programem Operacyjnym, Ministerstwo Rozwoju Regionalnego, http://www.funduszeeuropejskie.2007-2013.gov.pl/Dokumenty/wytycznepolskie/who/ Documents/wytyczne/Wytyczne_w_zakresie_procesu_kontroli_ob_IZ_PO_2007_2013 _proc_kontroli_30102014.pdf (dostęp: 10.04.2017).

24. Redo J. (2014), Przesłanki i eliminacja podwójnego finansowania w projektach wspótfinansowanych z Europejskiego Funduszu Społecznego, „Zeszyty Naukowe Wyższej Szkoły Bankowej we Wrocławiu", nr 6(44), s. 151-170.

25. Rozporządzenie Komisji (WE) nr 1828/2006 z dnia 8 grudnia 2006 r. ustanawiające szczegółowe zasady wykonania rozporządzenia Rady (WE) nr 1083/2006 ustanawiającego przepisy ogólne dotyczące Europejskiego Funduszu Rozwoju Regionalnego, Europejskiego Funduszu Społecznego oraz Funduszu Spójności i uchylającego rozporządzenie (WE) nr 1260/1999 (Dz. Urz. UE L 45/3, 15.2.2007).

26. Rozporządzenie Parlamentu Europejskiego i Rady (UE) nr 1303/2013 z dnia 17 grudnia 2013 r. ustanawiające wspólne przepisy dotyczące Europejskiego Funduszu Rozwoju Regionalnego, Europejskiego Funduszu Społecznego, Funduszu Spójności, Europejskiego Funduszu Rolnego na rzecz Rozwoju Obszarów Wiejskich oraz Europejskiego Funduszu Morskiego i Rybackiego oraz ustanawiające przepisy ogólne dotyczące Europejskiego Funduszu Rozwoju Regionalnego, Europejskiego Funduszu Społecznego, Funduszu Spójności i Europejskiego Funduszu Morskiego i Rybackiego oraz uchylające rozporządzenie Rady (WE) nr 1083/2006 (Dz. Urz. UE L 347/320, 20.12.2013).

27. Rozporządzenie Parlamentu Europejskiego i Rady (UE, EURATOM) nr 966/2012 z dnia 25 października 2012 r. w sprawie zasad finansowych mających zastosowanie do budżetu ogólnego Unii oraz uchylające rozporządzenie Rady (WE, Euratom) nr 1605/2002 (Dz. Urz. UE L 298/1, 26.10.2012).

28. Rozporządzenie Rady (WE) nr 1083/2006 ustanawiające przepisy ogólne dotyczące Europejskiego Funduszu Rozwoju Regionalnego, Europejskiego Funduszu Społecznego oraz Funduszu Spójności i uchylające rozporządzenie (WE) nr 1260/1999 (Dz. Urz. UE L 210/25, 31.7.2006).

29. Rydzewska-Włodarczyk M. (2011), Wybrane zagadnienia kontroli projektów wspólfinansowanych ze środków europejskich, „Zeszyty Naukowe Uniwersytetu Szczecińskiego. Finanse, Rynki Finansowe, Ubezpieczenia", nr 41, s. 295-310.

30. Szymański M. (2010), Zwrot środków nieprawidłowo wykorzystanych przy realizacji programów Unii Europejskiej. Na podstawie przepisów ustawy o finansach publicznych, „Kontrola Państwowa”, R. 55, nr 2(331), s. 116-126.

31. Szymański M. (2012), Kontrola projektów w ramach polityki spójności, „Kontrola Państwowa", R. 57, nr 3(344), s. 9-31. 
32. Urząd Marszałkowski Województwa Zachodniopomorskiego (2015), Zasady dotyczace odzyskiwania środków w ramach Regionalnego Programu Operacyjnego Województwa Zachodniopomorskiego 2014-2020, Zarząd Województwa Zachodniopomorskiego Instytucja Zarządzająca Regionalnym Programem Operacyjnym Województwa Zachodniopomorskiego 2014-2020, http://www.rpo.wzp.pl/sites/default/files/zal_10_zasady_dotyczace_odzyskiwania _srodkow.pdf (dostęp: 10.04.2017).

33. Ustawa z dnia 27 sierpnia 2009 r. o finansach publicznych (Dz.U. $2009 \mathrm{nr} 157$ poz. 1240, z późn. zm.) http://isap.sejm.gov.p1/DetailsServlet?id=WDU20091571240 (dostęp: 23.04.2017).

34. Zysińska M. (2007), Ewaluacja, monitorowanie $i$ kontrola projektów europejskich, [w:] Grucza B., Trocki M. (red.), Zarzadzanie projektem europejskim, PWE, Warszawa, s. 223-235.

\section{DETECTION OF DOUBLE FUNDING IN EU PROJECT}

Abstract: The article presents the prohibition of double funding as a general principle of EU funds management as well as the instruments implemented in the financial perspective 2007-2013 in Poland to exclude the situation in with the same costs can be financed twice from public funds. Moreover, the work contains the characteristic of cross checks instruments used by all Managing Authorities of Operational Programmes and the Coordination Institution of National Strategic Reference Framework and information about irregularities detected in double funding area. The article also presents the results of interviews conducted with representatives of Managing Authorities of Innovative Economy Operational Programme. The survey have showed the reasons for double founding and proposed remedies.

Keywords: European Union funds, cross checks, double funding 